\title{
ВОЗМОЖНОСТИ УЛУЧШЕНИЯ ФУНКЦИИ ПЕЧЕНИ У МУЖЧИН С САХАРНЫМ ДИАБЕТОМ 2 ТИПА В СОЧЕТАНИИ С ДЕФИЦИТОМ ТЕСТОСТЕРОНА
}

\author{
Рассказова М.А., Аллахвердиева Я.С., Дзантиева Е.О., Хрипун И.А., Воробьев С.В.
}

ФГБОУ ВО «Ростовский государственный медицинский университет» МЗ России, г. Ростов-на-Дону

Сочетание сахарного диабета 2 типа (СД2Т) и дефицита тестостерона (Т) у мужчин способствует увеличению распространенности ассоциированных заболеваний, в том числе и неалкогольной жировой болезни печени (НАЖБП). Влияние заместительной терапии Т (ЗТТ) на течение НАЖБП остается неизученной.

ЦЕЛЬЮ РАБОТЫ бЫла оценка влияния ЗТТ на выраженность НАЖБП У мужчин с СД2Т.

МАТЕРИАЛЫ И МЕТОДЫ: в исследование вошли 50 муЖчин в возрасте 40-65 лет (средний возраст $54,2 \pm 0,42$ года), страдающих СД2Т в сочетании с гипогонадизмом, установленным согласно критериям Российской ассоциации эндокринологов 2016 года. Все пациенты прошли клинические обследования, изучение показателей углеводного и жирового обменов; уровней общего Т; ферментов печени аланинаминотрансферазы (АЛТ), аспартатаминотрансферазы (АСТ), гамма-глутамилтранспептидазы (ГГТП), билирубина; а также магнитно-резонансную томографию (МРТ) печени с количественной оценкой фракции жира (FF). Пациенты были рандомизированы на 2 группы. В 1 группу ( $\mathrm{n}=24)$ вошли мужчины, которым была назначена 3ТТ в виде трансдермального 1\% геля-Т; 2-я группа ( $\mathrm{n}=26)$, контрольная, была представлена пациентами, не получавшими 3ТТ. Группы были сопоставимы по всем исходным показателям, длительности и терапии СД2Т. Терапия СД2Т была неизменной на протяжении исследования. Длительность наблюдения составила 6 месяцев. Статистический анализ результатов исследования проводился с помощью программы STATISTICA 10.0 с использованием критерия Вилкоксона для оценки показателей в динамике и U-теста Манна-Уитни для межгрупповых сравнений.

PЕзУЛЬTAты: на фоне 3ТТ в 1 группе было выявлено достоверное снижение массы тела $(\mathrm{p}=0,004)$ и индекса массы тела ( $p=0,003)$, наблюдалась статистическая тенденция к уменьшению окружности талии $(p=0,053)$ по сравнению с исходными. Это было ассоциировано со статистически значимым снижением уровней гликемии натощак $(p=0,02)$, общего холестерина $(p=0,002)$, триглицеридов $(p=0,04)$ и тенденцией к уменьшению $\mathrm{HbA}_{1 c}(\mathrm{p}=0,09)$ в 1 группе по сравнению с исходными. Исследование выявило статистически значимое $(p<0,01)$ снижение ферментов печени АЛТ на $38 \%$, АСТ на $14 \%$, ГГТП на $33 \%$ у пациентов 1 группы, тогда как уровни билирубина оставались прежними. Во 2-й группе достоверных различий не было получено. Это сопровождалось достоверным снижением FF по данным MPT печени с 10,2 $\pm 1,5$ до $7,1 \pm 1,4 \%(p=0,001)$ в 1 группе наряду со статистически незначимым $(p=0,117)$ ее повышением во 2 группе с $14,3 \pm 2,4$ до $15,9 \pm 2,4 \%$.

ВЫВОДЫ: включение 3ТТ в комплексное лечение мужчин с СД2Т в сочетании с гипогонадизмом приводит к уменьшению выраженности НАЖБП и улучшению функции печени.

БЛАГОДАРНОСтИ. Работа выполнена за счет средств Государственного задания № 14.

КЛЮЧЕВЫЕ СЛОВА: печень; тестостерон; неалкогольная жировая болезнь печени, гипогонадизм, андрогенный десицuт. 